DOI:10.24193/tras.59E.2

Published First Online: 2020/02/27

\section{BRAIN DRAIN IN THE EU: \\ LOCAL AND REGIONAL PUBLIC POLICIES AND GOOD PRACTICES}

\section{Emil BOC}

\section{Emil BOC}

Associate professor, Political Sciences Department, Faculty of Political, Administrative and Communication Sciences, Babes-Bolyai University, Cluj-Napoca, Romania

Tel.: 0040-264-431.505

E-mail: boc@fspac.ro than 2,000 years ago or when the first European universities were established. The debate is far from over and the issue is debated both at the academic and political level.

There are several interconnected levels at which the issue needs to be addressed and solutions found: local, regional, national, and supranational (EU). Coordination of different funding sources should be improved at the EU level in the governance of post-2020 cohesion policy and programs.

The local and regional authorities can best analyze the specific needs of communities and find answers to them and thus play an important role in reducing the potential negative effects of brain drain processes and can support brain gain, brain regain and brain circulation processes. There are many examples of public policies and practices implemented by local and regional authorities - from supporting the relocation of talented individuals to those regions/cities to more sophisticated measures involving the development of transnational networks of entrepreneurs. The EU needs to support programs or initiatives that aim to enhance learning between different European local and regional authorities and the efforts of local and regional public bodies in addressing brain drain.

Keywords: brain drain, brain gain, brain circulation, good practices.

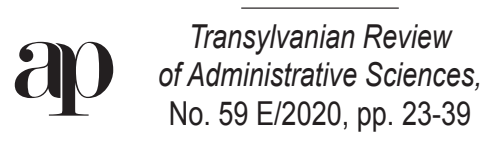




\section{Introductory remarks}

The emigration of highly qualified people has been and still is at the center of the academic and political debates since the 1960s (Kone and Özden, 2017, pp. 12-18). The debates first had a predominantly theoretical approach and proposed a balanced vision, which showed that, beyond the advantages of the countries of destination, there are advantages and disadvantages for the countries of origin. In the 1970s, the paradigm that was imposed in approaching the problem was one that emphasized the negative effects of the loss of human capital on developing countries. During this period, the Bhagwati tax was proposed which would allow the countries affected by the brain drain to receive financial compensation. This vision is still present in the specialized scientific papers and in the political public discourse. In the 1990s the problem has begun to be addressed in a balanced way, in terms of a negative and positive impact paradigm, and studies showed that there are/can be economic and social gains for the countries of origin, and under certain conditions there is an increase in the level of human capital. Recent empirical contributions have shown that the negative effects are generally limited (a limited effects paradigm) and that the gains from highly skilled emigration can be relevant if there are institutions in the countries of origin that can address the issue in terms of 'brain circulation' (via exchange programs and mobility fellowships) and development of networks of cooperation (and not just in terms of 'brain drain' vs. 'brain gain'). These gains include dissemination of knowledge, growth of foreign direct investment, growth of trade and sums of remittances to the sending countries.

In connection to the brain drain, 'brain waste' processes (or 'deskilling') which refer to migrants whose skills are either underutilized or not utilized at all as well as processes of 'brain regain' have been documented (improved human capital). The debate is far from over and the issue is debated both at the academic and political level.

\section{Addressing the challenge in the EU}

\subsection{An age-old problem}

The circulation of scientists and highly qualified persons has been the basis for the development of science since ancient times. Migration of educated people is more than 2,000 years old. Around 300 B.C., there was a brain drain from Athens to Alexandria, in the context of the policies promoted by Ptolemy I Soter. Later, the history of the first European universities is related to brain circulation and measures that tried to stop the brain drain phenomenon. In 1274, an edict published in Bologna stated: 'By this edict, we solemnly forbid any ecclesiastical or lay person, Bolognese or foreign, either personally or by messenger, letter or other means, to attempt to negotiate with ecclesiastical or lay persons, colleges, universities, regions, communes, or communal entities, the transfer of the studium of the city of Bologna to another place'. Other laws later advocated the same repressive approach (including the death penalty). Neither of them has proven effective: the Universities of Arezzo (1215), Padua (1222), 
Vercelli (1228), Sienna (1246), Pisa (1343), and Florence (1349) were founded after migrations from the University of Bologna (Dedijer, 1969, pp. 3-5).

For thousands of years, European science has meant exchanging ideas and disseminating discoveries in mathematics, physics, astronomy, biology, technique, and so on across the continent. European countries have benefited in the modern age from the circulation of ideas and brain circulation, managing to link scientific discoveries to technological innovations and thus to obtain important economic and social achievements.

\subsection{Freedom of movement - a fundamental value of the EU}

Within the framework offered by the European construction, any public policy regarding the brain drain phenomenon must take into account the foundations on which the European Union is built, and freedom of movement is a fundamental value of the EU. As stated in the Treaty of Lisbon, it represents one of the most important achievements of our Union:

'1. Freedom of movement for workers shall be secured within the Union. [...] 3. It shall entail the right, subject to limitations justified on grounds of public policy, public security or public health: (a) to accept offers of employment actually made; (b) to move freely within the territory of Member States for this purpose; (c) to stay in a Member State for the purpose of employment in accordance with the provisions governing the employment of nationals of that State laid down by law, regulation or administrative action' (Article 45).

The European model is based on respect for human rights and fundamental freedoms. Thus, the EU cannot refuse a right that is acknowledged by the Universal Declaration of Human Rights: 'Everyone has the right to leave any country, including his own, and to return to his country' (article 13) and 'No one shall be arbitrarily deprived of his nationality nor denied the right to change his nationality' (article 15).

The European model is based on social justice and solidarity. The free movement of goods, people, services and capital is possible only under the conditions of European solidarity. The social contract, as it can be understood from all EU programmatic documents, since the Treaty of Rome, is based on assumed common values: democratic institutions, human rights, social justice. And social justice is incompatible with mobility restrictions (Dumitru, 2012, pp. 9-11).

Thus, mandatory service measures or measures of taxation prior to departure or programs of taxation after departure - which have been, are and are likely to be brought up by politicians in various countries - are illiberal and violate European treaties. Everyone is free to move voluntarily inside the European Union, but no one should be forced to leave the country due to poverty and other economic reasons. 


\subsection{The knowledge economy - driver of intra-EU mobility}

The European Commission's regulated professions database provides evidence on the most mobile professions in the EU, showing that highly skilled people are among the most mobile (2012-2019 period, Country of qualification: All EU Countries; Host country: All EU Countries, https://ec.europa.eu/growth/tools-databases/regprof/ index.cfm, 16.08.2019): Nurse $(65,568)$, Secondary school teacher $(55,868)$, Doctor of medicine (52,975), Dental practitioner (14,309), Physiotherapist $(13,947)$, Architect $(8,460)$, Veterinary surgeon $(7,772)$, Lawyer/Barrister/Solicitor $(6,823)$, Nursing assistants and Health care assistants $(5,354)$, Auditor/Accountant $(5,267)$, Primary school teacher $(5,228)$, Pharmacist $(4,841)$, Kindergarten teacher/Nursery school teacher/Preparatory school teacher $(3,551)$, Midwife $(3,489)$, Psychologist $(3,116)$, Radiographer/ Radiotherapist $(2,615)$, Fork lift truck operator $(2,377)$, Engineer $(2,199)$, Speech and language therapist $(1,866)$, Child care worker $(1,842)$.

The knowledge economy is an important driver of intra-EU mobility and in particular of the mobility of highly skilled migrants and the regions where knowledge economy is developed are usually those that have developed physical and technological infrastructure, quality education system, cultural activities, medical care system, good connectivity among businesses and universities, to put it simply, good labor conditions and high quality of life. The knowledge economy is shaping the mobility of highly qualified persons: migration flows follow east-west, south-north and rural-urban patterns, and sending regions have an average GDP per capita that is $64 \%$ of the EU28 average, whilst receiving regions have an average GDP per capita that is $108 \%$ of the EU28 average (Busetti et al., 2017 apud Cavallini et al., 2018, p. 9).

A study that considered 23 countries in the EU and Switzerland (Grecu and Titan, 2016, p. 65) showed that the 'country capacity to retain talent' index is strongly positively correlated with 'life expectancy' (0.922), 'quality of overall infrastructure' (0.654) and 'quality of the educational system' (0.729).

According to a study commissioned by the European Committee of the Regions (Cavallini et al., 2018, pp. 11-12), in 2017, there were almost 17 million people who changed their residence within the EU, of which about one third $(32 \%)$ were in the age group 15-34 years. Most people who relocated in the EU went to Germany and the United Kingdom, the most important countries of origin being Romania, Poland, Italy and Portugal. Of the people who moved in the EU and were of active age (15-64 years), a proportion of $25 \%$ had a tertiary level of education. Highly qualified people have very high employment rates and have favorite destinations in the northern areas of the Union (Sweden, Ireland, Estonia, Denmark, and United Kingdom). The highest number of highly qualified people moving within the EU came from Poland (576,300 individuals), Germany (472,700), and Romania (467,500).

A World Bank study shows that Bulgaria, Croatia and Romania are countries with high levels of external migration for health workers, while they have vacancies in their health sectors. The highly skilled workers in Romania have the highest emi- 
gration rate, $27 \%$ of the total of the highly qualified Romanians living abroad in 2017 (World Bank, 2019, pp. 63-65).

A study on the movement of skilled labor showed that, between 2004 and 2016, the proportion of high skilled EU movers among the employed population in the EU tripled, to a total of 3.6 million in 2016. The benefits of high skilled EU movement were equally distributed among the Member States, because the largest mobility flows are from Central and Eastern European countries to the more developed countries (ICF, 2018 , p. 3). The study shows that there are a number of factors that act on macro, meso and micro levels behind the individual migration decisions of skilled workers, factors that are interdependent. These are: at the macro-level: economic environment (GDP, income levels), labor market situation (unemployment, wages), quality of life, working and living conditions, institutional environment and stability, geography; at the meso-level: migration policy framework, size of diaspora communities; at the micro-level: age, gender, education level, family responsibilities, spoken languages (ICF, 2018, p. 77). Also, the study showed that the migration flows of skilled persons are influenced by the public policies developed at the transnational, national, regional and local level involving a wide range of stakeholders, showing that systemically there are four major types of interventions: policies and practices relevant prior to moving, policies and practices to support arrival, integration and networks, policies and practices to support qualification recognition, policies and practices to support return migration (ICF, 2018, pp. 124-125).

If we look at the percentage evolution of EU mobile citizens as a share of the resident population of their country of citizenship, we note that, between 2008 and 2018, Romania has had the highest percentage increase, of 11.8 percentage points. In 2018,

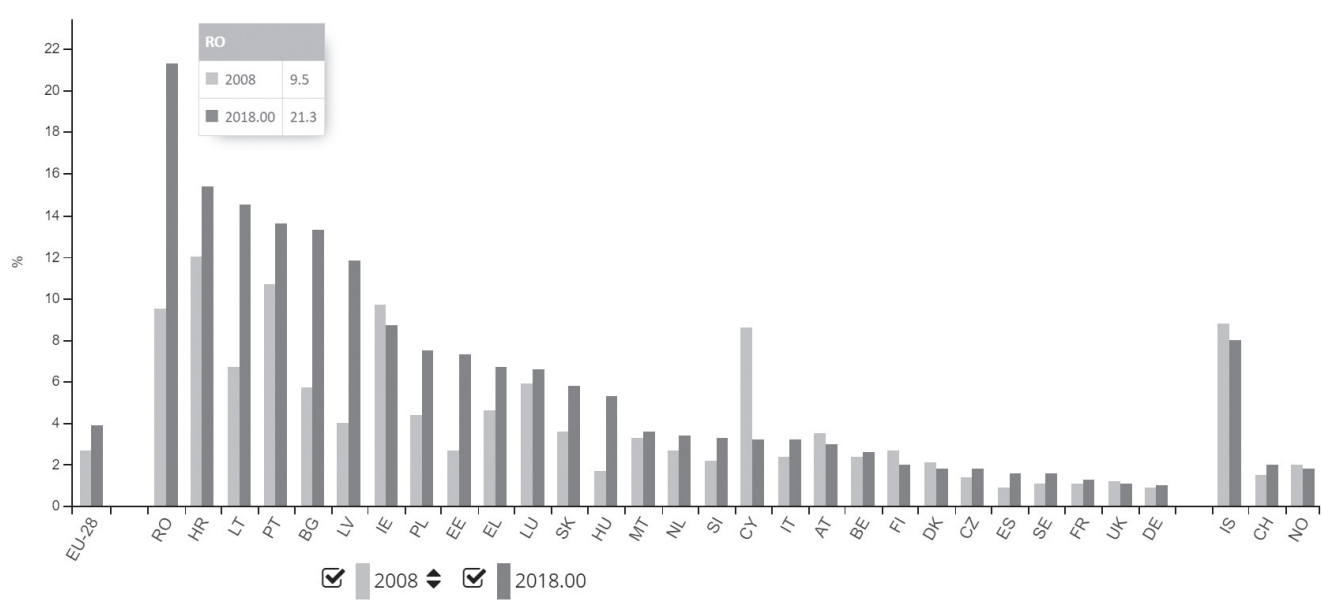

Figure 1: EU mobile citizens of working age (20-64) by country of citizenship, \% of their home-country resident population (In descending order of \% in 2018; Figure of low reliability for 2008: Estonia, Luxembourg, Malta and Iceland; Figure of low reliability for 2018: Malta and Iceland)

Source: Eurostat (2019) 
Romanian citizens of working age (20-64) residing abroad within the EU accounted for $21.3 \%$ of the population residing in Romania, followed by Croat citizens (15.4\%) and Lithuanian citizens (14.5\%). At the other end of the picture we find Germany $(1.0 \%)$ and the United Kingdom (1.1\%). In absolute numbers, in 2018, the most numerous groups were those from Romania $(2,524,000)$, Poland $(1,666,000)$, Italy $(1,133,000)$, Portugal $(824,000)$ and Bulgaria $(562,000)$. During the same period, the share of the highly skilled amongst groups of mobile EU citizens aged 20-64 grew by 8.9 percentage points.

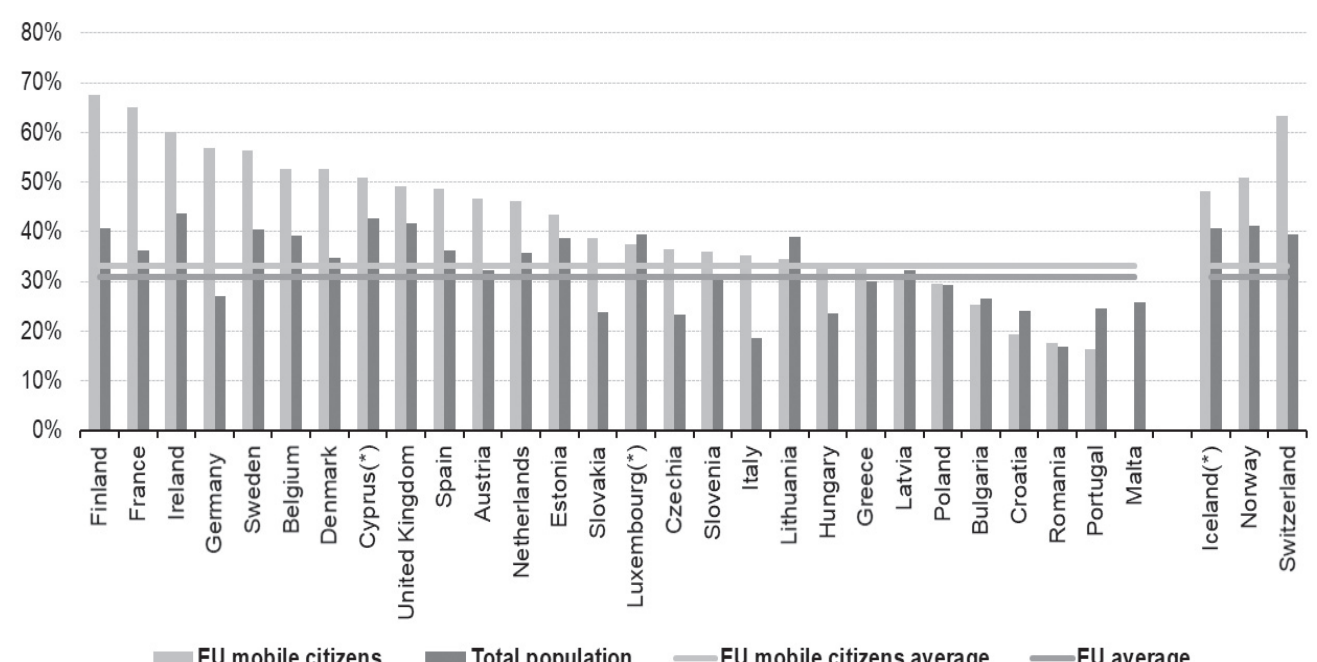

Figure 2: Population aged 20-64 with tertiary educational attainment (ISCED 5-8) by country of citizenship, 2018 (In descending order by \% among EU mobile citizens; (*) Figure of low reliability for EU mobile citizens)

Source: Eurostat (2019)

\subsection{Tackling brain drain: leadership and coordination}

Inequalities and differences in earnings and living standards are what generate and maintain the brain drain phenomenon (Lutz et al., 2019, p. 9). When we talk about brain drain at the European Union level we talk about the need to improve working and living conditions throughout Europe. 83 million Europeans (one in six EU residents) live in low-income and low-growth regions (Widuto, 2019, p. 5). This is the fundamental problem to be solved - any public policy meant to manage the brain drain phenomenon must attack the root causes: the economic development, the recovery of the gaps between the European states, the socio-economic climate, the functioning of the rule of law (respecting the rule of law represents a fundamental premise for a favorable environment for economic and social development). Economic, social and territorial cohesion is the foundation that must be ensured, both from a financial and symbolic perspective. Analyzing the realities of different European countries and regions where flows of high skilled migrants are registered (especially young migrants) and the cor- 
relation of these flows with the evolution of socio-economic disparities is the foundation on which EU policies will have to be based after 2020, in particular the policy of cohesion. Increasing the quality of life is what every European citizen in the Union expects. The political commitment of the new Commission (von der Leyen, 2019, p. 9) for a 'fair minimum wage' is of high relevance especially in sender regions, as it tackles the issue of living standards, working conditions and directly influences the quality of life.

There are several - often interconnected - levels at which the issue needs to be addressed and solutions found: local, regional, national, and supranational (EU). Therefore coordination of different funding sources should be improved at the EU level in the governance of post- 2020 cohesion policy and programs, so as to guarantee more coherence of agendas at different governance and planning levels in the short to medium term (Hermansons, 2019, p. 18).

In the context in which in the European public sphere, in recent years a 'two-speed Europe' has been discussed, it should be noted that a two-speed Europe would only accentuate the negative effects of the brain drain. If it aims to overcome the brain drain vs brain gain paradigm, the EU needs more integration, not new barriers; it needs a vision that sees legitimate national interests as being fulfilled in the EU. In the absence of such an approach, we are heading to a Europe with winners and losers (the brain gain vs. brain drain approach being an example that illustrates this unwanted situation).

In the regions and cities without jobs, with high unemployment among young people and unable to access minimum quality of life it is not surprising that brain drain processes are in progress. European reality demands that elected politicians take on public policies regarding real and pressing needs. In this context, in many countries it would be desirable to have more decision-making power for the authorities closest to the citizen. Modern technology should also be used to improve people's lives and communication with European citizens. The mechanisms of civic participation need to be rethought and given greater importance (co-creation, co-participation).

It is a strategic objective to improve labor market conditions in order to ensure equality between women and men, a fundamental right, a common value of the European Union and a necessary condition for achieving the objectives of economic growth and social cohesion. Recent studies showed that there are highly skilled migrant women whose potential is undervalued, and in such cases there are processes of brain waste (Riaño, 2012).

In Central and Eastern Europe, the brain drain phenomenon manifests itself in particular in the IT\&C and medical fields, but it is present everywhere where talented and educated people leave and settle in richer societies, where they find opportunities and/or a better quality of life for them and their families, being a global phenomenon. And the EU is one of the attractions for talented and educated people globally.

In the new programmatic framework, the EU could assume the funding of programs that provide knowledge spillover effects in the source countries of migration flows and should assume financing educational programs to ensure people's access to opportunities in the source countries of migration flows. 
Migrants send remittances to their families at home and thus help the economic development of the countries of origin. A study that took into account migrants from Europe (considered as a geographical region containing 45 countries and not just the EU space) showed that, in 2014, there were 19 European countries with an annual GDP per capita below US $\$ 20,000$ that had received remittances, of which $10 \mathrm{EU}$ member countries receiving a total of US \$ 20.5 billion, and 9 non-EU countries in eastern and southern Europe receiving nearly US \$ 16 billion (IFAD, 2015, pp. 6-7). However, economic development, particularly sustainable development, requires not only money, but also functional institutions and a system of good governance. Creating better institutions is an important aspect of development (Brock and Blake, 2015, pp. 37-40) and it is desirable to increase the administrative capacity of institutions in European countries that are affected by the brain drain phenomenon. Also, reducing bureaucracy and increasing transparency at all levels of administration are prerequisites for economic and social development.

Given the global competition that makes highly qualified people easier to find jobs in non-EU countries that invest heavily in research \& development projects and in the conditions of global competition and the aging or declining populations in the larger EU economies (Cedefop, Eurofound, 2018, p. 35), the EU needs the ability to propose bold and innovative projects that attract young talents, as the plan on Artificial Intelligence (European Commission, 2018) or the programs to ensure the future of the European space sector (de Concini and Toth, 2019).

Closer cooperation between European research institutions and increased mobility of knowledge workers is desirable. From this deeper cooperation between research institutes and European universities, on the one hand, and between these institutions of knowledge and the business environment, we expect technological solutions that will provide economically viable answers to the major problem of climate change and sustainable economic development. The ability to innovate and transform these innovations into economic development is specific to Europe, and supporting existing networks, expanding and strengthening them at European level is a foundation from which we can find appropriate answers to the problems of the contemporary world.

The recent program for the European Universities Initiative will have to be developed in the future as it is of major importance to reduce the disparities between European countries by creating cooperation networks, and to ensure the highest academic standards, for the presence of Europe in the global competition. The potential impact of the European Universities Initiative for the whole European construction is very high (including to be able to consolidate the 'brain circulation' paradigm in the EU instead of 'brain drain' vs. 'brain gain' paradigm).

Two of the key Europe 2020 objectives, increasing the percentage of employed people and improving social inclusion, are relevant to creating favorable conditions which will diminish brain drain. Other Europe 2020 objectives, such as innovation and increasing the number of people in tertiary education, could potentially lead to brain gain and brain regain. 
It is worth noting also the new Commission's support for increasing the budget of the Erasmus+ program and the objective for a European Education Area by 2025 (von der Leyen, 2019, p. 14).

\section{Public policies and good practices used by local and regional authorities (LRAs)}

\subsection{Recommendations for public policies and good practices at the EU level}

The most comprehensive comparative study on intra-European brain drain (Cavallini et al., 2018) analyzes 30 initiatives related to fighting brain drain and/or favoring brain gain at the local and/or regional levels (pp. 19-69). These initiatives are 30 examples of good practices to reduce the negative impact for sending regions and also for the entire system, meaning for both sending and receiving regions, and to increase the positive impact for receiving regions and also for sending regions.

It is worth noting that these examples of good practice are widespread throughout Europe, in Western Europe and in former communist countries alike.

The study showed that although there is a close correlation between socio-economic conditions and brain drain processes, there is a dynamic brain drain (sending) brain gain (receiving) and that LRAs can take an active attitude and implement public policies to create a favorable socio-economic environment for attracting talent.

Also a series of recommendations have been made for LRAs, which represent action benchmarks for the future, not just for LRAs, but for any authority, institution or organization that wants to address the brain drain issue:

- R1: 'Investigate and understand the needs of talent' (Cavallini et al., 2018, pp. 71-73).

It is important that sending and receiving regions become aware of the brain drain phenomenon and its specific characteristics (including the target groups to be addressed and their expectations). Various research methods in the social sciences can be used.

In a case study regarding the cross border region of Greece and Bulgaria and targeting young scientists (Cavallini et al., 2018, p. 27), the policy makers were not fully aware that the highly qualified women were leaving rural areas. In a case study regarding Umbria region (Cavallini et al., 2018, pp. 57-59) and targeting citizens of the region who are residing abroad, in-depth study of the reasons for the migration of local talents allowed the regional authorities to establish incentives for the return of highly skilled persons.

Establishing a dialogue with the young talents proved to be very important, as have shown the case studies regarding the Strategy of Greater Copenhagen (target group: international talents), and regarding Salzburg Model Region (target groups: young people, women) (Cavallini et al., 2018, pp. 46-49 and p. 22).

Understanding the causes of migration is the basis on which both public authorities and the business environment can build measures to stop brain drain processes and to achieve regaining talent (Iacob, 2018, p. 55). 
- R2: 'Coordinate players and synergize resources for talent-based growth' (Cavallini et al., 2018, pp. 73-74). It involves the creation of processes of cooperation between the relevant social actors, having at their center the social actors creating competencies (e.g. universities) and social actors demanding skills (e.g. businesses), but also considering other social actors. The challenge is to build an ecosystem based on trust and collaboration - an ecosystem that includes both physical and virtual space - in which there is not only a match, but also a mutual enhancement between the need for highly skilled individuals and the supply of talent.

The brain drain issue can be addressed in terms of the multiple-helix based approaches/mechanisms or in the terms of 'sustainable innovation' proposed by Hautamäki and Oksanen (2015, pp. 87-102) for addressing complex problems, a holistic vision and an inclusive approach, looking for solutions generated in ways that include all stakeholders and cooperation between all social actors, considering that the economic success of a solution must also be evaluated in terms of the impact on existing social practices.

There are several examples of good practices based on complex cooperation processes, notably 'The Talent House of San Sebastián' (Cavallini et al., 2018, pp. 51-54), which it has set out to attract and receive international researchers, branding San Sebastián as an innovative, talented and smart city in which it is desirable to live. The creation of dedicated infrastructures such as the Talent House building provided the R\&D community with a physical place where it can network with other local stakeholders (e.g. businesses operating in the $\mathrm{R} \& \mathrm{D}$ sector, the local community) and exchange research outputs with effect on economic activity. Also, the development of municipal accommodation service proved to be beneficial for the city's reputation.

- R3: 'Identify and support key driving sectors for retaining/attracting talent' (Cavallini et al., 2018, pp. 74-75). LRAs can and should focus on 'sectors they are actually investing in from a strategic point of view (e.g. through Smart Specialization Strategies)', but it is just as important to explore new opportunities, as did the city of Thessaloniki, which supported cultural and creative industries and involved civil society in the process (pp. 49-51).

- R4: 'Stimulate the absorption of outside talent' (Cavallini et al., 2018, pp. 75-76). Talents must be attracted (including here regaining talent that had previously moved away). Attracting talents is related to investments in R\&D activities and facilities offered to the talent established in the city/region or returning to the city/region, but is also related to the attention paid to the quality of life and branding (as in the example of San Sebastián). And talents want to be publicly recognized and communities need to know their talents. One such example that aims to create brain gain and brain circulation is 'South Moravian Program for Distinguished Researchers' (pp. 43-45), a grant scheme for projects carried out by young Czech researchers who had research experience abroad. They were encouraged to return to the region 
and participate in collaborative research, which has contributed to the growth of regional ecosystem's innovation capacity.

- R5: 'Mitigate/remove structural impediments/barriers to attracting international talents' (Cavallini et al., 2018, p. 77). LRAs should make available to interested parties accurate and complete information and to provide services and facilities outside of the job sphere, to create and maintain the necessary infrastructure to ensure the quality of life in the city/region and to pay attention to improving the mentality (cultural differences or the presence of gender-biased mentality may built barriers). The Welcome-Service-Pinzgau (target groups: young people, women, p. 22) offers child care and housing search services.

- R6: 'Cooperate with other authorities facing the same challenges with regards to highly skilled workers' (Cavallini et al., 2018, pp. 78-79).

First, this last recommendation refers to finding solutions based on cooperation and the ability to share limited resources, as was the case in The Zasavje region and the City of Zagorje ob Savi (Slovenia, target groups: highly skilled people under 35 years, pp. 63-65), in the cross border regions of Hungary and Croatia (target groups: young graduates, pp. 37-38) or in the case of various municipalities and national institutions from the Amsterdam Metropolitan Area in 'Open Amsterdam!' project (target groups: international talents and their families, pp. 32-33).

Secondly, the recommendation refers to the opportunity to participate in EU financially-supported projects, with authorities from different Member States having several tools at their disposal. Co-funding of the projects can be done through the European Regional Development Fund, through participation in URBACT (e.g. Municipality of Varna project, target groups: young people, p. 23) and Interreg (e.g. 'Network of Medium Sized Creative Cities' project involving Municipality of Arnhem (lead partner) (NL), Bremeninvest (Bremen's economic development agency) (DE), Municipality of Iasi (RO), City of Presov (SK), European Business and Innovation Center of Navarra (ES), target groups: creative talent, pp. 38-39). Other good practice cases have shown that cooperation between different authorities can be financially supported by specific programs such as the Europe for Citizen Program (Harghita County Council, target groups: young people, p. 34) and the Alpine Space Program (Regional Government of Salzburg, target groups: young people, women, p. 22).

At the EU level, employment and social policies, education and training systems are organized and implemented by the Member States, and the EU supports Member States through policy cooperation (via the social pillar, initiatives such as the Youth Guarantee, or the New Skills Agenda for Europe and the 'Education and Training 2020 ' framework) and funding instruments (including the Erasmus+ program and the European Structural and Investment Funds). 


\subsection{Public policies and good practices in Cluj-Napoca}

According to a World Bank study, if they had the opportunity to move to any city in the country, $15.32 \%$ of Romanians would move to Cluj-Napoca, which is the most attractive city in Romania from this perspective. $15.32 \%$ of the respondents answered that they would move to Cluj-Napoca, attracted by: the quality of life, the medical care services in the city, the university education, the jobs, the dynamic cultural-artistic environment, and the active economic environment (Cristea et al., 2017, pp. 115-116; the results of a survey realized between 25-31 March 2017, where people were asked where they are thinking of moving in the future; the survey was submitted to a representative sample of 1,250 people in Romania, the margin of error is $+/-2.83 \%$ for a $95 \%$ confidence interval). Moreover, Cluj-Napoca, an academic center and an important economic, cultural and civic center of Romania, is the most attractive secondary city in Romania according to the Magnetism Index, an indicator that takes into account the total stable population, the number of students, the companies' turnover per capita, average salary, investments per capita, distance from Bucharest (Cristea et al., 2017, pp. 108-109).

Cluj-Napoca is relying on knowledge economy in making the city attractive for highly skilled workers. Cluj-Napoca is an IT and innovation hub - number of employees in IT\&C: approx. 22,600 (Petrovici and Mare, 2020, p. 48). Cluj-Napoca was one of the cities that, after the financial crisis, changed its local economy and the composition of the labor force, becoming a hub in four transnational fields: IT\&C, support services for business, engineering \& research \& development, financial services. This development has allowed the city to be part of the group of $50 \mathrm{EU}$ cities (in 2018), which have a GDP (PPP) per capita of 19,000-27,000 euro and which have demonstrated a credible commitment to promoting knowledge, culture and creativity. The city ranks $16^{\text {th }}$ among the 50 cities, even though the overall performance is lower than the group average. Cluj-Napoca comes in the ranking immediately after Athens and Liverpool, followed by Limoges and Katowice. The best performance was recorded for the dimension evaluating newly created jobs in the creative sector $-9^{\text {th }}$ place among the 50 European cities (Petrovici and Mare, 2020, p. 30).

In this context, we can consider that the city has managed, at least in part, to find response to the negative effects of brain drain and supports the development of brain gain and brain circulation processes.

In the following I will present, briefly, some elements of policies and practices developed at the level of the Cluj-Napoca municipality that facilitate the attraction and retention of talents. At the City's Strategy level, development is defined in terms of 'the quality of life of its inhabitants', proposing 'to maintain a balance between economic growth and social cohesion' (Boc, 2017, p. 7), 'support for innovation' and 'excellence in services'. The key strategic factors are: Innovation; University; Participation. The City's Strategy was realized together with the specialists from the Babeș-Bolyai University and with the broad participation of civil society structures. 
The governance model adopted is a multiple helix (Peris-Ortiz et al., 2016, pp. 8-9) participatory governance model, which includes the public administration, universities, the private economic sector, organized civil society (NGOs) and citizens, each social actor and every citizen being considered as having the capacity to define and to find solutions to public problems and as having the right to participate in decision making (Boc, 2018, p. 62). In this framework of an inclusive public sphere, dialogue with young people with a high qualification is built, as is the dialogue with young people who do not have a high qualification.

In order to achieve a structured dialogue between all the social actors, the municipality initiated several participatory governance tools: participatory budgeting (in Cluj-Napoca, participatory budgeting processes were initiated for the first time in Romania), the Advisory Council for Entrepreneurship and Innovation in IT and the Civic Creativity and Innovation Center (CCIC). CCIC is a laboratory of ideas in which different forms of collaboration between the actors in the city are developed and tested. CCIC promotes the debate on the projects started in the last years that have in their center the increase of the quality of the public space, and encourages the involvement of citizens in community development projects.

In this framework, Cluj-Napoca seeks and finds solutions to increase the quality of life on multiple levels: providing an urban infrastructure that is aimed at people and not cars; green mobility (electric public transport - more than $1 / 3$ of the public transportation fleet is electric and the entire fleet will be electric by 2030, dedicated lanes, bike sharing system, etc.), safety of the citizens, protection of the environment and energy efficiency, green spaces (parks and urban gardens) and the use of water courses (the municipality has adopted the solution of organizing international competitions for public space works with major impact on the quality of life, such as, for example, the rehabilitation of the banks of the Somess river), efficient medical care system, balanced development of different neighborhoods, application of technology in administration for simplification and for reducing bureaucracy, supporting cultural activities (in particular the projects undertaken in the candidature in the European Capitals of Culture project), promoting the competitive advantages of the city/region at European and global level, development of the educational system at all levels and child care policies (out of every 5 lei paid by the inhabitants of Cluj-Napoca on taxes, at least 1 leu goes to the City Hall's programs supporting access to education).

Particularly important are public policies and practices for child care and access to education programs on multiple levels: preschool level (investing in nursery and kindergarten infrastructure - there are 10 projects in various phases for the construction of new nurseries and kindergartens or for the complete rehabilitation of existing ones); school and high school level (modernizing and equipping the pre-university education units, free public transport for students, transport for students with special needs, introducing special routes for school buses, granting scholarships for all the students who meet the conditions - over 16,000 scholarships each semester, prizes and public recognition for students with special results and for their teachers); uni- 
versity level (collaboration to solve the problem of related infrastructure, ensuring the connection between the economic environment and universities in order to adapt the curricula with the demands on the labor market, free public transport for students); postgraduate level - 'Young Researchers in Science and Engineering Prize'.

In 2015, the City Hall of Cluj-Napoca, responding to an initiative from the academic environment (from Rada Flavia Mihalcea, professor of Computer Science, University of Michigan), initiated the project 'Young Researchers in Science and Engineering Prize', an initiative aimed at rewarding young researchers (up to 35 years old) who have demonstrated their excellence and made significant contributions through their work, rewarding them with monetary grants and, indirectly, signaling their innovative potential to local businesses (Cavallini et al., 2018, pp. 33-34). The competition has an Evaluation Commission which includes teachers from relevant universities worldwide, from Europe and USA.

The municipality has developed support policies for investors, including here incentives for investors: fiscal facilities - regional state aid schemes and de minimis state aid schemes; incentives for green buildings - the reduction of the tax on the building in the case of buildings which have an official certification recognized worldwide (LEED, BREEAM or DGNB) as 'green building' (A class); innovative policy to support office buildings instead of malls or real estate (more than 340,000 sqm office spaces in the city in 2019); business clubs for business support.

The City Hall implemented two economic projects that benefited from European funding: the Regional Center of Excellence for Creative Industries (CREIC) and the Business Support Center Technology, Evolution, Entrepreneurship, Microenterprises - Cluj Metropolitan Area (TEAM-ZMC), both in the Lomb area. CREIC and TEAMZMC are part of Cluj Innovation Park, representing a core of development in the north of the city.

Cluj-Napoca is the first city in Eastern Europe to receive a $98 \%$ grant from the European Commission, through the Urban Innovative Actions program, in a project that proposes a strong partnership between the local administration and the cultural, academic, business and social Sectors. The project 'Cluj Future of Work' is worth 5.6 million Euros and aims to analyze and test scenarios that allow the cultural, academic, business and administration sector and, in general, the community to prepare for the changes on that the next 20 years will bring to the labor market.

It is worth noting that Cluj-Napoca may be considered the Romanian capital of clusters ( 8 business clusters with: 393 member companies, 8 member universities, 5 partner public institutions, 22 catalyst organizations in 2019) and, also, a startup city. Considering a startup as a company which, in the first three successive years since its establishment, has annual increases of minimum $20 \%$ of the revenues, 901 start-ups were active in the Cluj Metropolitan Area in 2018, representing 4.3\% of the total number of companies (Petrovici and Mare, 2020, p. 43). 


\section{Conclusions}

There are no miraculous answers to the questions raised by the 'brain drain' and 'brain gain' processes, which are complex processes, with benefits and losses for all parties involved, the quantification of which is still the subject of academic and political debate.

However, it is important to continue the integration at the EU level, to ensure economic, social and territorial cohesion with sensitive effects in the daily life of all European citizens and to respect the fundamental principles on which the EU is built. A socio-economic climate favorable to technological and social innovation at the level of each Member State and at the level of the whole EU represents the fundamental premise for stopping the departure of young specialists and for the return of the departed.

Realistic policies to attract, retain, and re-attract an educated workforce can be designed and implemented and there is a need to develop an integrated European approach to brain drain based on realistic assessments, cooperation and coordination at local/regional, national and Union levels.

National authorities have the primary responsibility for providing the legislation and regulatory framework for creating the conditions and the socio-economic climate necessary to reduce the phenomenon of 'brain drain', but at the same time, local and regional authorities are the ones closest to citizens and have knowledge of the local economy and the labor market, they can analyze the specific needs and find answers to them and they can play an essential role in the creation and development of innovation ecosystems that connect the institutions of knowledge, the economic environment and civil society.

There are many examples of public policies and practices implemented by local and regional authorities - from supporting the relocation of talented individuals to those regions/cities to more sophisticated measures involving the development of transnational networks of entrepreneurs. Starting from the examples of good practices known at the EU level, it is desirable to build a form of structured dialogue between local and regional authorities for the exchange of best practice models. A collaboration platform based on a common understanding and generosity to share ideas is a basis for institutional development at local and regional level, for providing assistance and for developing cooperation networks, even if there are a number of elements that mediate transferability (e.g.: specific competences of local and regional authorities, national labor policy and regulatory framework, available resources, education system). This collaboration can build projects that benefit from access to the resources offered by various EU programs, share experiences and understand different perspectives of actors from different Member States. And the European Commission should actively support - in close cooperation with the European Committee of the Regions, the European Parliament and the EU Council of Ministers - the efforts of local and regional public bodies in addressing brain drain. 


\section{References:}

1. Boc, E., 'Cluj-Napoca Smart City: More than Just Technology', in Hintea, C., Moldovan, B.A., Radu, B.V. and Suciu, R.M. (eds.), Transylvanian International Conference in Public Administration, Cluj-Napoca, Romania, 2-4 November 2017, Cluj-Napoca: Accent, 2018, pp. 57-73.

2. Boc, E., 'Inovare sustenabilă pentru un oraș colaborativ' (Sustainable Innovation in a Collaborative City), 2017, Revista Transilvană de Ştiinţe Administrative, vol. 40, no. 1, pp. 3-12.

3. Brock, G. and Blake, M., Debating Brain Drain. May Governments Restrict Emigration?, New York: Oxford University Press, 2015.

4. Busetti S., Drufuca, S., Melloni, E., Patrizio,, M., Lodovici, M.S., Vasilescu, C., Barbone, L., Speckesser, S., Hadjivassilio, K., Marvell, R., Manzo, C., Green, M., Brück, A., Hillmann, F., Gajewski, J., and Ślęzak, E., 'The Geography of New Employment Dynamics in Europe, Luxembourg: ESPON, 2017.

5. Cavallini, S., Soldi, R., Di Matteo, L., Utma, M.A., Errico, B.., Addressing Brain Drain: The Local and Regional Dimension, European Union, 2018.

6. Cedefop, Eurofound, Skills Forecast: Trends and Challenges to 2030, Luxembourg: Publications Office, Cedefop reference series No 108, 2018.

7. Cristea, M., Mare, C., Moldovan, C., China, A., Farole, T., Vințan, A., Park, P., Garrett, K.P. and Ionescu-Heroiu, M., Magnet Cities. Migration and Commuting in Romania, Washington, DC: World Bank, 2017.

8. De Concini, A. and Toth, J., The Future of the European Space Sector. How to Leverage Europe's Technological Leadership and Boost Investments for Space Ventures, European Investment Bank, 2019.

9. Dedijer, S., 'The Brain Drain: An Age-Old Problem', European Community, no. 127, September 1969, pp. 3-5.

10. Dumitru, S., 'Skilled Migration: Who Should Pay for What? A Critique of the Bhagwati Tax', 2012, Diversitie, vol. 14, no. 1, pp. 9-23.

11. European Commission, 'Statistics - Professionals Moving Abroad', [Online] available at https://ec.europa.eu/growth/tools-databases/regprof/, accessed on August 16, 2019.

12. European Commission, $\operatorname{COM}(2010)$, 'EUROPE 2020 - A Strategy for Smart, Sustainable and Inclusive Growth’2010.

13. European Commission, Fact Sheet, 'Questions and Answers: Coordinated Plan for Artificial Intelligence 'Made in Europe”, Brussels, 7 December 2018.

14. European Union, 'Treaty of Lisbon Amending the Treaty on European Union and the Treaty Establishing the European Community', 2007/C 306/01, 2007.

15. European University Foundation, 'Position Paper on the European University Initiative', Luxembourg, April 2018.

16. Eurostat, 'EU Citizens Living in Another Member State - Statistical Overview', [Online] available at https://ec.europa.eu/eurostat/statistics-explained/ index.php/EU_citizens_liv ing_in_another_Member_State_-_statistical_overview\#Who_are_the_most_mobile_EU_ citizens.3F, accessed on July, 2019.

17. Grecu, M. and Titan, E., 'Brain Drain - Brain Gain, Evidence from the European Union', 2016, Journal of Applied Quantitative Methods, vol. 11, no. 3, pp. 61-69. 
18. Hautamäki, A. and Oksanen, K., 'Sustainable Innovation: Competitive Advantage for Knowledge Hubs', in Lappalainen, P., Markkula, M. and Kune, H. (eds.), Orchestrating Regional Innovation Ecosystems. Espoo Innovation Garden, Aalto University in cooperation with Laurea University of Applied Sciences and Built Environment Innovations RYM Ltd, 2015, pp. 87-102.

19. Hermansons, Z. Daly, G., Gauk, M. and Raugze, Llona (eds), 'Addressing Labour Migration Challenges in Europe', Luxembourg: ESPON, 2019.

20. Iacob, R., 'Brain Drain Phenomenon in Romania: What Comes in Line after Corruption?' 2018, Romanian fournal of Communication and Public Relations, vol. 20, no. 2, pp. 53-78.

21. ICF, 'Study on the Movement of Skilled Labour. Final Report', Luxembourg: Publications Office of the European Union, 2018.

22. International Fund for Agricultural Development, 'Sending Money Home: European Flows and Markets', 2015.

23. Kone, Z.L. and Özden, C., 'Brain Drain, Gain, and Circulation', Global Knowledge Partnership on Migration and Development Working Paper 19, March 2017.

24. Lutz, W. (ed.), Amran G., Bélanger A., Conte A., Gailey N., Ghio D., Grapsa E., Jensen K., Loichinger E., Marois G., Muttarak R., Potančoková M., Sabourin P., and Stonawski M., Demographic Scenarios for the EU. Migration, Population and Education, Luxembourg: Publications Office of the European Union, 2019.

25. Peris-Ortiz, M., Ferreira, J.J., Farinha, L., Fernandes, N.O. (eds.), Multiple Helix Ecosystems for Sustainable Competitiveness, Cham: Springer International Publishing, 2016.

26. Petrovici, N. and Mare, C., Economia zonei metropolitane Cluj și a municipiului Cluj-Napoca. Transformări între 2008 și 2018 (The Economy of the Cluj Metropolitan Area and of Cluj-Napoca. Transformations between 2008 and 2018), Cluj-Napoca: Centrul Interdisciplinar pentru Știința Datelor, Universitatea Babeș-Bolyai, 2020.

27. Riaño, Y., 'The Invisibility of Family in Studies of Skilled Migration and Brain Drain', 2012, Skilled Migration and the Brain Drain, vol. 14, no. 1, pp. 25-62.

28. United Nations General Assembly, 'The Universal Declaration of Human Rights', 217 A (III), 1948.

29. Von der Leyen, U., A, 'Union that Strives for more. My Agenda for Europe. Political Guidelines for the Next European Commission 2019-2024', 2019.

30. Widuto, A., 'Regional Inequalities in the EU', European Parliamentary Research Service, 2019.

31. World Bank, 'Migration and Brain Drain. Europe and Central Asia Economic Update', Washington, DC: World Bank, 2019. 